\title{
Feminismo Decolonial
}

\author{
Decolonial Feminism
}

\author{
Susana de Castro \\ Docente do departamento de filosofia da UFRJ/PPGF
}

Resumo: $\mathrm{O}$ trabalho traz um apanhado das questões que norteiam o feminismo decolonial. O objetivo do artigo é mostrar que a matriz eurocêntrica do vocabulário de luta feminista atrapalha a elaboração de um modelo de feminismo que abarque o racismo estrutural dos países que foram colonizados. No lugar do vocabulário iluminista dos direitos é preciso construir pontes de interlocução com o feminismo negro revolucionário e com a filosofia ameríndia do Bem Viver.

Palavras-chave: Decolonialidade; Racismo; Eurocentrismo; Bem Viver

Abstract: This paper gives an overview of the issues that guide decolonial feminism. The aim of it is to show that the Eurocentric matrix of the feminist struggle's vocabulary hinders the elaboration of a model of feminism that embraces the structural racism of the countries that were colonized. Instead of the illuminist vocabulary of rights, it is necessary to build bridges of dialogue with revolutionary black feminism and the Amerindian philosophy of Good Living.

Keywords: Decoloniality; Racism; Eurocentrism; Good Living 
O movimento feminista surge com a luta das mulheres pelo direito ao voto. A luta por direitos iguais aos homens segue a lógica do vocabulário político emancipatório introduzido a partir da perspectiva iluminista europeia de universalização dos direitos e igualdade. Se todos somos iguais, não é justo que as mulheres tenham menos direitos do que os homens. Muitas vezes esquecemos essa origem europeia, iluminista do feminismo. Mas o grupo Modernidade/Colonialidade que agregou diversos intelectuais latino americanos a partir de meados da década de noventa (BALLESTRIN, 2013), pôs duramente em questão o projeto iluminista-moderno da Europa, principalmente porque sob a capa de progresso e emancipação deu suporte teórico ao projeto colonial racista.

$\mathrm{O}$ projeto europeu moderno é marcado pela ideia de racionalidade universal e de sujeito do conhecimento, isto é, pela noção de que os fundamentos do conhecimento verdadeiro estão no próprio sujeito. Para a perspectiva moderna, portanto, o que nos torna seres excepcionais na natureza é a nossa racionalidade. Mas que racionalidade é essa? O que percebemos é que essa racionalidade possui DNA, ou seja, ela reflete um contexto histórico, o do surgimento do capitalismo, sendo, portanto, culturalmente localizada. Trata-se da universalização de um modo de reflexão, de um modelo de racionalidade, a racionalidade instrumental. É essa racionalidade instrumental que vai justificar o modelo econômico do capitalismo nascente, de acumulação de capital com o emprego da mão de obra escrava e de exploração dos recursos naturais das colônias ultramarinas. Esse modelo de racionalidade se tornou de fato universal, porque atrelado ao domínio político e econômico da América pelas potências europeias na época da colonização. Os europeus não só tomaram as terras dos povos originários, mas também tomaram sua dignidade, na medida em que lhe impuseram o regime de trabalho forçado, reprimiram seus hábitos e costumes sociais, culturais e religiosos. Esse processo de dominação pelo imaginário, de desenraizamento cultural dos povos originários se assemelha a situação dos povos africanos trazidos da África para a América. A retirada forçada de seus países de origem, o desmantelamento de seus laços familiares 
e nacionais, somados à situação iníqua da escravidão, foram estratégias de opressão e dominação física e psíquica utilizadas pelos colonizadores escravocratas. A política e a economia europeia estavam assentadas no racismo colonial. O branco europeu se autoelegeu padrão de superioridade racial e cultural, de tal modo que os outros povos, os não europeus, deviam lhes seguir os passos a fim de se aperfeiçoarem política e culturalmente (QUIJANO, 2000).

A proposta do feminismo decolonial é romper com qualquer noção de ponto de partida universal comum, abstrato, para o feminismo. Primeiro, não é possível falar em nome da mulher em abstrato, como propõe o feminismo tradicional, já que a experiências de vida e de história das mulheres são culturalmente diferenciadas. Segundo, por baixo do machismo ainda há uma outra opressão, mais violenta e que lhe serve de base, o racismo colonial. Enquanto habitantes da periferia do capitalismo mundial, o povo brasileiro é ainda hoje obrigado a ceder seu imaginário de desejo ao imaginário consumidor do capitalismo global, pois todas as formas alternativas de sociabilidade e expressão cultural não hegemômicas, isto é, não europeia-norteamericana, são consideradas inferiores e, por isso, estigmatizadas.

Uma vez que o vocabulário comum das lutas emancipatórias, tais como direitos civis, direitos humanos, autonomia, liberdade, igualdade, entre outros, originam-se do liberalismo moderno e do iluminismo, o feminismo decolonial o coloca na berlinda. Seguindo sua fundadora, a argentina Maria Lugones (2008), o feminismo decolonial mostra que as sociedades pré-colombianas não estavam sujeitas à mesma divisão sexual de tarefas que a europeia e como consequência dessa situação histórica, seus descendentes nos chamados países periféricos, ex-colônias, herdam estratégias de vida e de sobrevivência, hábitos e formas de sociabilidade, diferentes da norma eurocentrada.

A diferença colonial, entre colonizador e colonizado, introduzida pela empresa colonial para justificar a exploração da mão de obra do não europeu racializado também significou uma diferença territorial, entre a colônia e a metrópole. A diferença territorial significou que nas colônias não havia regras 
nem limites para a tomada da terra e de seus recursos, enquanto na Europa, as regras eram o que impediam os estados nacionais de invadirem o território do outro (SCHMITT, 2014). Essa diferença territorial trouxe consequências devastadoras não só para as ex-colônias, mas para o planeta. Seguindo Alberto Acosta (2016), considero que o modelo extrativista, predatório, antropocêntrico, do capitalismo global, nos conduz a um suicídio planetário. O modelo de sociabilidade liberal-moderno privilegia o indivíduo acima de tudo. Herdeiros desse modelo, o mundo ocidental que havia estigmatizado as formas de sociabilidade comunitária dos povos originários começa a perceber que os povos originários detém uma forma de socialização avançada. O individualismo exacerbado leva ao adoecimento, ao isolamento. A competitividade torna o ambiente de convivência entre os pares um ambiente de disputa.

Na perspectiva decolonial, faz-se necessário hoje mais do que nunca o resgate das experiências de vida dos povos originários, na verdade, de todas as experiências não ocidentais que tenham uma cosmovisão holística. Essa cosmovisão holística é representada na América Latina pela noção do Bem Viver, comum a várias etnias indígenas no Equador, na Bolívia e no Brasil (ACOSTA, 2016). 'Bem viver' se opõe ao 'viver melhor' ocidental. O segundo está baseado na ideia de que uma boa vida depende do avanço progressivo do desenvolvimento tecnológico, isto é, na ideia de que as futuras gerações terão cada vez mais acesso a novas tecnologias, em um processo de melhoramento ao infinito. O primeiro, ao contrário, considera que o valor maior é a defesa da vida. Não há vida boa se a natureza é destruída. A defesa da vida deveria ser um princípio ético supremo. Hoje, está mais do que claro que o desenvolvimento econômico atrelado ao desenvolvimento científico tecnológico não atinge a população do planeta. O capitalismo liberal vende a ilusão de que ao seguir sua receita os Estados trarão prosperidade para todos, mas é evidente que essa tese é falsa. O desenvolvimento econômico de uns depende da pobreza de outros. Os chamados países periféricos precisam ser pobres para que os países centrais do norte possam manter o estilo de vida, o viver melhor, de seus habitantes. 
Apesar de mais de cinco séculos de dominação, os grupos dos povos originários andinos e da Amazônia continuam resistindo ao capitalismo e mostrando que uma outra forma de organização social e econômica é possível. Uma organização política e econômica que considere o ser humano como parte da natureza e não o seu dono. Não é possível que consideremos normal o acumulo indiscriminável de riquezas na mão de poucos. A ciência e a tecnologia a serviço do capital só servem para aprofundar as diferenças entre os países. É nesse sentido que Acosta (2016) alerta para a falsidade do projeto de desenvolvimento proposto pelos países centrais aos países periféricos, pois não é material nem racionalmente possível que toda a população do planeta venha a ter os mesmos padrões de consumo dos países industrializados, seja porque nesse caso o planeta colapsaria, seja porque de fato no capitalismo a desigualdade é um pressuposto; a riqueza de uns depende da pobreza de outros. Dessa maneira, baseando-se na experiência comunitária e de defesa da vida, da natureza, dos povos originários, Acosta sugere que deixemos de lado o viver melhor do capitalismo ocidental e adotemos o bem viver das comunidades andinas e amazônicas (2016).

Em consonância com a proposta do Bem Viver, o feminismo decolonial reivindica que seja dado protagonismo às experiências das mulheres que até hoje resistem à violência racista e colonialista. Suas pautas estão bem próximas ao feminismo negro e ao feminismo das mulheres de cor (YUDERKYS, 2016). Irmana-se com a proposta de bell hooks de feminismo revolucionário (2018), isto é, um feminismo que lute para o fim da exploração das mulheres que realizam o trabalho de outras mulheres, como o trabalho doméstico. A luta contra a exploração das mulheres negras ou indígenas é uma luta de todos, homens e mulheres, pois é uma luta não só contra a opressão do patriarcado, mas também contra a opressão econômica do capitalismo. O feminismo revolucionário busca mudar a sociedade como um todo, não somente a situação das mulheres. Não adianta ganhar mobilidade social para alguns grupos de mulheres, se na base continuarmos a ter mulheres em situação de exploração, mal remuneradas, sem direito à assistência de 
saúde adequada, ou vítimas de assédio e violência. Uma das marcas daquilo que Maria Lugones cunhou de 'sistema colonial moderno de gênero' está justamente na ausência de solidariedade entre os homens e mulheres nos países que sofrearam a colonização europeia. Para Lugones (2008), a falta de solidariedade atual entre homens e mulheres latino americanos é um resultado direto da colonialidade. Ao longo do processo de colonização, homens e mulheres nativos foram considerados desprovidos de civilidade porque na concepção racista do europeu, os hábitos e costumes dos nativos eram bestiais, mais próximos da animalidade do que da humanidade. Os nativos aos olhos dos europeus eram machos e fêmeas, não homens e mulheres. No processo de aculturação, os assim chamados 'machos' e 'fêmeas' foram se tornando forçadamente 'homens' e 'mulheres', cabendo ao homem, em seu papel de chefe da família, exercer seu domínio sobre as mulheres. A dominação patriarcal surge no colonialismo como forma de dar a ilusão ao nativo de que ele detinha também algum tipo de poder. Essas marcas do colonialismo permanecem até hoje como uma das formas de colonialidade do poder, o poder sobre o sexo. Quijano divide o poder colonial racista em poder sobre o trabalho e seus produtos, poder sobre o sexo e seus produtos e poder sobre o governo e suas instituições. Para Lugones, Quijano erra ao adotar a mesma linguagem europeia objetificadora da mulher ao elencar o controle sobre o sexo e seus produtos como um dos campos de disputa do poder colonial, pois na verdade não havia um poder patriarcal em curso nas sociedades pré-colombianas, o patriarcado surgiu com o colonialismo.

Não há hoje por parte dos latino-americanos o entendimento de que a luta pela libertação da sociedade contra o julgo da colonialidade eurocentrada, ou norte-americano-centrada, passe também pela luta das mulheres contra a opressão de classe, de cor e de sexo.

É preciso assumir o ponto de partida etnocêntrico, ou seja, o ponto de partida segundo o qual falamos desde um lugar geográfico e desde um contexto cultural e histórico. Essa realidade cultural é responsável por nos oferecer modos de identifi- 
cações com os quais devemos, entretanto, manter uma atitude crítica tendo em vista o racismo estrutural que permeia toda sociedade eurocentrada.

Os processos de identificação ocorrem a partir das relações intersubjetivas, ou seja, é o olhar do outro que me constitui e eu de volta o constituo - mas, dependendo da relação de poder, o olhar de um vai se sobrepor ao do outro: o homem sobre o da mulher, o patrão sobre o do empregado, a patroa sobre a empregada doméstica.

O feminismo negro mostrou através do conceito de interseccionalidade que uma mulher cujo corpo é racializado, ou seja, é identificado como não-branco, sofre uma forma de discriminação que fica invisibilizada a partir da lógica dos direitos civis, cuja dinâmica fragmenta as diversas discriminações: ela não é vitima apenas de discriminação de gênero, mas de discriminação de gênero e de raça ao mesmo tempo.

Finalmente, o feminismo decolonial mostra que é preciso abrir nossa mente para formas de comunicação não verbais para que entendamos porque a lei punitiva não consegue alcançar a experiência da discriminação. Não basta usar indiscriminadamente o vocabulário dos direitos humanos como se isso fosse o suficiente para solucionar todos os problemas sociais. É preciso mudar a sociedade e a cultura.

As filosofias anti-essencialistas da contemporaneidade nos mostram que não é somente o argumento que convence o outro. É uma ilusão achar que o aparato institucional da democracia liberal, e seus fóruns de deliberação, sejam suficientes para convencer as pessoas de que devemos diminuir as desigualdades de gênero, de classe e de raça. Formas de comunicação não verbais, artísticas, e relatos de experiência são outros caminhos e ferramentas que devem ser utilizados no processo de transformação da sociedade e da maneira como nos relacionamos uns com os outros. 


\section{Referências:}

ACOSTA, Alberto. O Bem Viver - uma oportunidade para imaginar outros mundos. Tradução Tadeu Breda. São Paulo: Autonomia Lieterária, Elefante, 2016.

BALLESTRIN, Luciana. "América Latina e o giro decolonial". In: Revista Brasileira de Ciência Política, n. 11. Brasília, 2013. P. 89-117.

LUGONES, Maria. "Colonialidad y Género". Tabula Rasa. N. 9. Bogotá, 2008. P. 73-101.

QUIJANO, Aníbal. Coloniaidad del poder, eurocentrismo y América Latina. Argentina, 2000.

"Colonialidad y Modernida/Racionalidad". In: Perú Indíg. 13 (29). Lima, 1992. P. 11-20.

SCHMITT, Carl. O nomos da Terra no direito das gentes do jus publicum europaeum. Trad. Alexandre Franco de Sá et. Alli. Rio de Janeiro: Contraponto, Editora PUC-Rio, 2014. 